\title{
Managing for soil health can suppress pests
}

by Amanda Hodson and Edwin Lewis

\begin{abstract}
A "healthy" soil can be thought of as one that functions well, both agronomically and ecologically, and one in which soil biodiversity and crop management work in synergy to suppress pests and diseases. UC researchers have pioneered many ways of managing soil biology for pest management, including strategies such as soil solarization, steam treatment and anaerobic soil disinfestation, as well as improvements on traditional
\end{abstract} methods, such as reducing tillage, amending soil with organic materials, and cover cropping. As managing for soil health becomes more of an explicit focus due to restrictions on the use of soil fumigants, integrated soil health tests will be needed that are validated for use in California. Other research needs include breeding crops for disease resistance and pest suppressive microbial communities as well as knowledge of how beneficial organisms influence plant health.

$\mathrm{T}$ The U.S. Department of Agriculture (USDA) Natural Resources Conservation Service (NRCS) defines soil health as the "continued capacity of soil to function as a vital living ecosystem that sustains plants, animals, and humans" (NRCS 2014), thus emphasizing that a healthy soil is one that yields both agronomic and ecological returns. Soil health emphasizes the dynamic, living nature of soil (van Bruggen and Semenov 2000), and encompasses biological attributes such as biodiversity, food web structure and ecosystem functioning (Pankhurst et al. 1997). These properties have been linked to important agronomic benefits such as disease and weed suppression, resilience to environmental stress and increased plant productivity (Berendsen et al. 2012;
Brussaard et al. 2007; Lehman and AcostaMartinez 2015; Pellkofer et al. 2016; van der Heijden et al. 2008; Wagg et al. 2014).

Precisely defining soil health can be a difficult task since it is determined by interactions among microbial communities, management decisions, and soil physical and chemical factors. Use of the term soil health has recently become more common (Farm Foundation NFP 2014; Ferris and Tuomisto 2015) and is used distinctly from soil quality, which describes agricultural productivity as well as a soil's quantitative physical and chemical characteristics (Doran et al. 1996; Singer and Ewing 2000). However, use of the term can be problematic, because some soil organisms that contribute to biodiversity can make it difficult for crops to grow, and could be considered unhealthy for agricultural production (McKenry et al. 1994).

Growers have used various tools to address the challenge of soil pests, which include fungi, bacteria and nematodes and which cause billions of dollars in economic damage each year. In the past, soil pest management technologies relied heavily on resistant plants and cultural modifications such as crop rotation, tillage and hand weeding. While these were helpful in preventing pest outbreaks, and are still widely used today, increased use of soil fumigants since the 1950s has provided additional rapid, effective and inexpensive pest management. Methyl bromide was particularly useful in that a single treatment before planting could effectively control many types of soilborne pests, resulting in increased crop yields and quality.

In 1999, a phaseout of methyl bromide began under the Montreal Protocol, an international treaty that limits the production of substances that deplete stratospheric ozone, commonly referred to as the ozone layer. While this treaty has allowed for quarantine/preshipment and critical use exemptions in many crops that do not have effective or affordable fumigant replacements, such as strawberry, these exemptions will soon phase out almost entirely.
Online: http://dx.doi.org/10.3733/ca.2016a0005
As soil fumigant use becomes more restricted, UC researchers are studying alternative pest supression strategies such as soil solarization, shown here, and anaerobic soil disinfestation.

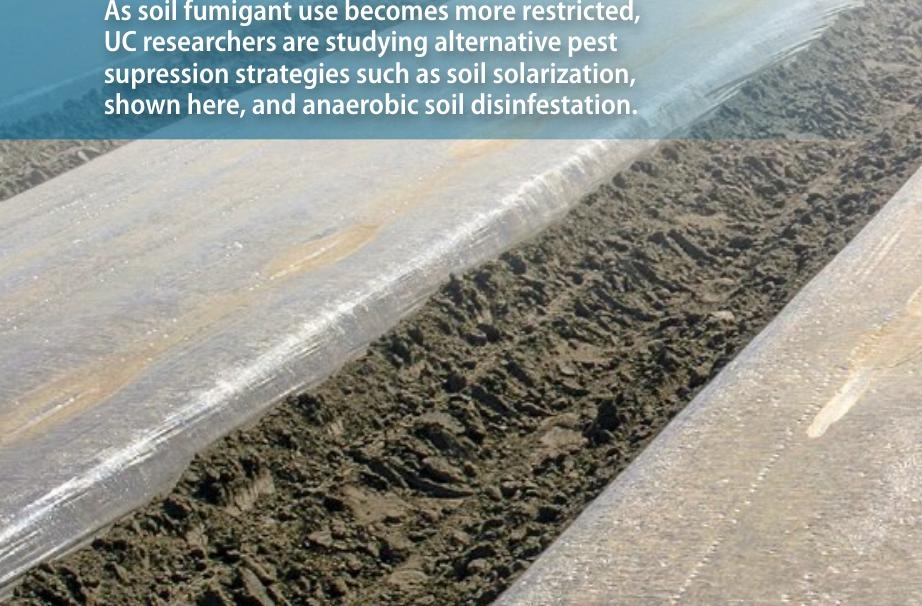


As the use of soil fumigants becomes more restricted by state and federal regulators, the question of how to sustainably manage agroecosystems to increase soil health has become more important. Recently, governmental organizations within California have taken more interest in managing for soil health, with the goal of simultaneously achieving high agronomic and ecological functioning without relying so heavily on fumigants (California Department of Pesticide Regulation 2014; NRCS 2014). While the University of California (UC) has historically been a leader in soil health research and fumigant alternatives, more research on soil health is needed to provide consistent pest control that manages the multiple economic and environmental tradeoffs involved. Here, we review research on managing soil health as a method of pest suppression, advances in soil health diagnostics and recommendations for future research priorities.

\section{Soil solarization, steam and ASD}

Soil solarization, steam and anaerobic soil disinfestation (ASD) disinfest the soil by creating conditions inhospitable for microbes. For example, solarization and steam elevate temperatures above those tolerated by many microbes, while ASD deprives microbes of oxygen; all three methods volatilize organic compounds naturally present in soil that are toxic to soil microorganisms (Hewavitharana et al. 2014). The technique of soil solarization has been extensively studied by UC scientists and is most effective at controlling pests that live in the top 12 inches of soil (Hartz et al. 1993; Stapleton et al. 2000). A modification on this technique, bisolarization, combines covering and heating the soil with the incorporation of plant materials, which enhances pest suppression (Gamliel and Stapleton 1993; Stapleton and Duncan 1998; Villapudua and Munnecke 1986). ASD builds upon these principles by combining the addition of organic matter and covering of the soil with flooding to create anaerobic conditions where microbes cannot survive (Shennan et al. 2014).

When used under the right conditions, all three methods can be very effective. For example, in small-scale strawberry production, solarization effectively
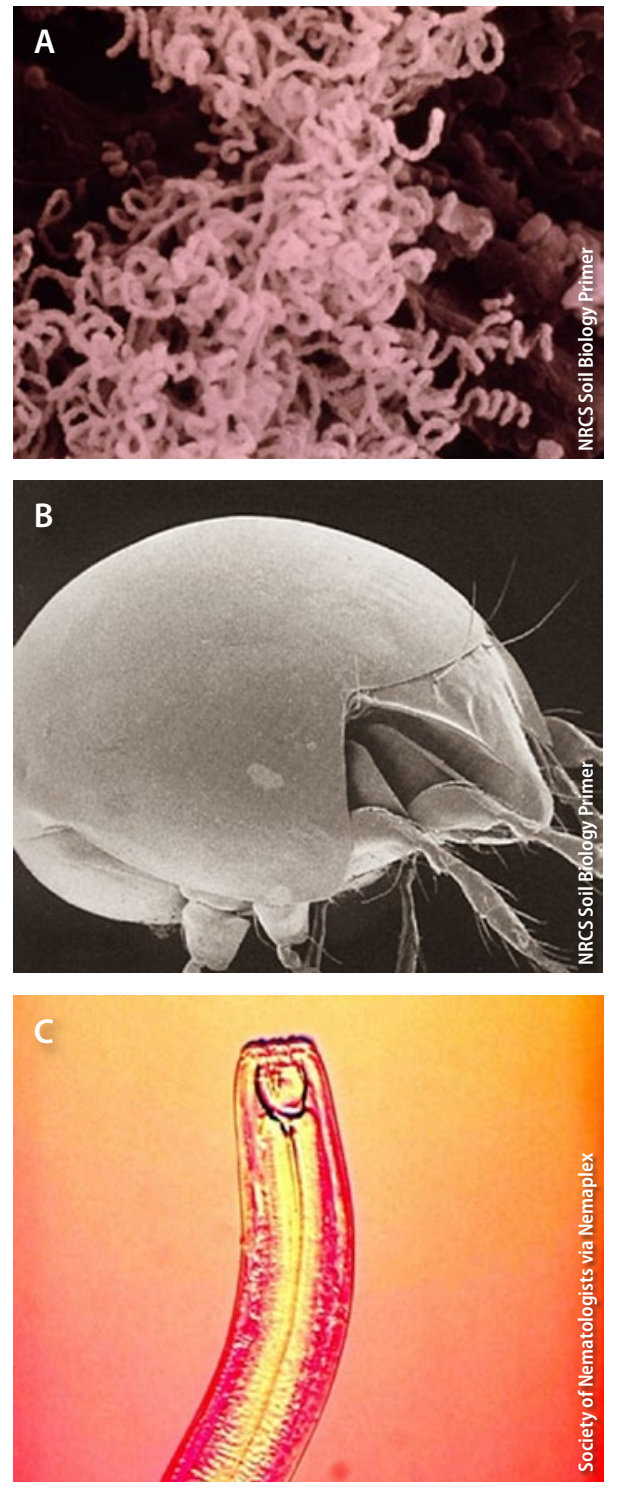

controlled weeds and was more cost effective than methyl bromide while providing similar yields (Stapleton et al. 2005). Steam and ASD treatments can also result in yields comparable to those produced in conventionally fumigated soils (Fennimore et al. 2013; Samtani et al. 2012). Steam treatments, long used in California nursery production to control nematodes and diseases (Baker 1948;

Baker and Smith 1967), were previously limited for field use by their slow speed (Samtani et al. 2012). However, recent UC and USDA Agricultural Research Service (ARS) research on applicators that physically mix soil with steam are faster and have shown promising results, paving the way for commercially available models (Fennimore et al. 2014).

While these methods kill pests directly, they can also cause biological
Examples of organisms that enhance soil health include (A) actinomycete bacteria, which decompose organic matter into compost $\mathbf{0 . 0 0 0 5}$ $\mathrm{mm}$ ), (B) turtle mites (Orobatidae), which shred plant material into pieces, facilitating decomposition $(0.05 \mathrm{~mm})$, and $(C)$ predatory nematodes (Monochidae), which regulate populations of pest nematodes ( $3 \mathrm{~mm}$ ).

changes that contribute to pest control. Opportunistic species of nematodes and microbes quickly re-colonize after treatment and many of these groups are antagonistic to pests (Gamliel and Stapleton 1993; Mazzola et al. 2012; Simmons et al. 2014; Stapleton 2000), resulting in very different microbial communities than those found in either fumigated or nonfumigated soil (Drenovsky et al. 2005; Shennan et al. 2013). For ASD, steam and solarization, researchers continue to explore using different amendments (e.g., rice bran, brassica seed meal) to enhance pest control and optimize the carbon sources used to control specific pathogens (Fennimore et al. 2014; Shennan et al. 2013; Shennan et al. 2014; Simmons et al. 2013).

\section{Cover crops and crop rotation}

Using cover crops and crop rotation can inhibit pathogens and weeds, as well as stimulate beneficial soil microbes. Incorporating cover crops can also produce bioactive compounds that behave similarly to chemical soil fumigants (biofumigation), causing changes in microbial communities and suppressing pests (Hao et al. 2003; Koike and Subbarao 2000). In peaches, UC and USDA-ARS researchers found that short preplant rotations of sudangrass helped manage Prunus replant disease, improving calculated profits even when fruit prices were low (Browne et al. 2013).

To optimize the potential of cover cropping, more information is needed about which planting mixtures and sequences best suppress pests. This information, along with data on the yield benefits provided by various planting mixtures, must be integrated into existing crop management systems for several reasons. Certain cover crops can be incompatible with the agricultural practices used on the main crop (Ingels 1994); others can have allelopathic effects on crop plants (Summers et al. 2009); and cover cropping may not be desirable for some particularly high value crops, or in cases where the appropriate cover crops for 
managing soil biology are not themselves economically profitable.

\section{Organic amendments}

While organic amendments possess widely different characteristics, and their effects can vary between production batches, they generally enhance soil microbial activity by providing carbon in forms that are easy for microbes to digest (Cavigelli et al. 2012; Janvier et al. 2007).

Over the years, UC research has focused on topics ranging from how mulches and composts can increase populations of nematode-trapping fungi (Jaffee 2004; Mankau 1959) to their effects on weeds and diseases (Jackson et al. 2003). The decomposition of organic amendments also increases soil temperatures, as in biosolarization, and helps create anaerobic conditions, as in ASD (Shennan et al. 2014; Stapleton and Banuelos 2009).

Amendments likely suppress pathogens and weeds by both producing biocidal or allelopathic compounds and by altering microbial communities, but the exact mechanisms of how this occurs remain unknown. Amendment with brassica seed meal residue, a byproduct of biodiesel production, controlled nematode pests and diseases in a study of two Washington state apple orchards, and resulted in higher yields compared to fumigated soil (Mazzola et al. 2015). In orchard soils, brassica seed meal can also suppress weed growth by modifying resident soil microbial communities (Hoagland et al. 2008). Treatments based on organic amendments can be optimized through research that examines their effects singly and in mixtures across different crops and soil types. However, care must be taken to eliminate risks of crop contamination with human pathogens. Useful research will also characterize and monitor soil microbial communities associated with plant disease suppression after the application of amendments (Mazzola 2004).

\section{Tillage}

Growers till soil to prepare seedbeds and kill weeds, but this also disturbs soil microbial communities (Cavigelli et al. 2012), which can have negative consequences for natural enemies of pests (Wardle 1995). UC research on the effects of no-till agriculture in cotton and processing tomatoes has found that sustained management of no-till practices can achieve yields comparable to standard tillage (Mitchell, Klonsky et al. 2012; Mitchell et al. 2015) and can reduce seed banks of weeds (Shrestha et al. 2008). Benefits of this method include lower labor costs (Mitchell, Klonsky et al. 2012; Mitchell, Singh 2012), reduced particulate matter emissions (Baker et al. 2005) and less evaporative water loss (Mitchell, Singh et al. 2012), as well as increased soil carbon (Veenstra et al. 2007). While these results have served as a proof-of-concept, further studies on the commercial feasibility of this technique are needed to determine whether it can be widely adopted by California processing tomato growers.

\section{Inoculation}

The previous practices could be considered methods of conservation biological control, which modifies agricultural practices and the environment to promote the establishment and survival of native organisms antagonistic to pests (Eilenberg et al. 2001). Another approach to biological control is inoculation, where natural enemies are released directly via soil, seeds or planting materials with the expectation that they will continue to provide control as they reproduce in the environment (Eilenberg et al. 2001). Past work in this area by UC scientists found that inoculation with certain species of root-colonizing bacteria (termed fluorescent pseudomonads or plant growth-promoting rhizobacteria) increased plant growth and suppressed diseases such as vascular wilt and take-all (Kloepper el al. 1980a; Kloepper et al. 1980b; Suslow et al. 1979). Recent work has identified new strain-specific genes in florescent pseudomonads that produce antibiotics, expanding potential avenues of disease suppression (Loper et al. 2012).

The strategy of inoculating soil with beneficial microorganisms requires further research in multiple areas. While inoculation with microbes can confer traits such as resistance to nematode pests (Flor-Peregrin et al. 2014) and environmental stress (Coleman-Derr et al. 2014), they often do not survive when introduced into a new environment and so are unable to control pathogens effectively (Mazzola 2004). For example,
UC researchers found that the microbial communities of soil where commercial inoculants were applied were similar to uninoculated soils, and that inoculants had no effect on tree vigor (Drenovsky et al. 2005). Advancing knowledge of how plants and microbes communicate and how key beneficial organisms function to influence plant health and/or repel pathogens may mitigate these constraints and improve the effectiveness of inoculated products. Inoculating crops with an assemblage of complementary microorganisms may also control diseases more effectively than inoculations with a single group. Such compatible microbial communities, or consortia, could also help restore diversity, leaving fewer available resources for pathogens to become established (Bakker et al. 2012).

\section{Breeding}

One long used strategy to control belowground pests has been the breeding of cultivars and rootstocks resistant to specific pests and diseases. UC research has been instrumental in identifying and evaluating genetic material resistant to a variety of soil pests and diseases, such as root knot nematodes (Kaloshian et al. 1996; Yaghoobi et al. 2005), Fusarium wilt (Scott et al. 2012) and Armillaria (Baumgartner et al. 2013). Recent field research evaluating experimental rootstocks for almond and stone fruit has found that some hybrids are markedly less sensitive to Prunus replant disease than others, which may result in less need for chemical controls (Browne et al. 2013). Molecular advances are also enabling the genes for resistance to be mapped and marked for easy identification, facilitating the development of improved germplasm in crops such as walnuts (Kluepfel et al. 2014).

Instead of breeding directly for disease resistance, another approach is to breed crops for root exudate characteristics that suppress pests, either by producing bioactive compounds or by recruiting diseasesuppressive microbes. The question of how plants and microbes communicate chemically and what plant exudates are important in shaping the microbial community has been examined for some plant species in the laboratory (Badri et al. 2009), but research remains sparse for agricultural crops. 
While we know that existing crop cultivars differ in their associated microbial communities (Smith and Handelsman 1999), breeding programs have rarely, if ever, taken an active approach to manipulate them (Mendes et al. 2013). On the contrary, modern crop breeding may have inadvertently selected against traits that fed beneficial microbes and encouraged their establishment. The theory of plantmicrobiome co-adaptation holds that crop plants grown close to areas where they were originally domesticated had the opportunity to form close associations with microorganisms over long time periods. As these crop plants were brought into new locations, though, they encountered microbial communities to which they were not adapted. Signals that may have triggered a beneficial response in the native community would then go "unheard" by microbes in the new cropping system (Bakker et al. 2012). Such a mismatch between the root microbial community and the plant could create an opportunity for pathogen infection. Since pathogens compete with other microbes for food and physical space on the root, a tight association with beneficial microbes may leave little room for pathogens to establish.

\section{Soil health diagnostics}

The soil health tests available at this time mostly focus on chemical and physical indicators (for example, water infiltration rate and plant-available nutrients) since these are generally straightforward to measure and interpret. As soil microorganisms and fauna intimately relate to soil physical properties and immediately affect ecosystem processing, their presence, abundance and diversity have often been proposed as bioindicators of soil health (Nielsen and Winding 2002; Visser and Parkinson 1992), but these indicators also require taxonomic expertise.

Currently in California, several tests related to soil health are available. The UC
Davis Analytical Laboratory measures soil physical and chemical factors like organic matter, carbon and bulk density, while the California Department of Food and Agriculture (CDFA) provides diagnostic services for plant pests, weeds and diseases. These resources are largely limited to those affiliated with university or government agencies, but private companies also identify many nematode species and other plant pathogens and perform soil analyses. Despite these assets, no specific soil health test is available in California that integrates multiple factors.

Other publically available soil health tests in the United States provide indices that combine different suites of indicators. The Haney Soil Health Test, available through the USDA-ARS, gives a soil health score in addition to measuring plant-available nutrients. The score is calculated based on overall microbial activity, the food resources available to microbes (in the form of water extractable carbon and nitrogen) and the ratio of carbon and nitrogen in the sample. The Comprehensive Assessment of Soil Health (offered through the Cornell University Nutrient Analysis Laboratory) provides indicators of many soil processes, including disease presence, microbial activity and nutrient storage and release. For both of these tests, adjusting the soil health scores and management recommendations to local crops, soils and management practices, as well as on-farm validation, will improve their relevance and accuracy for use in California.

\section{Future directions}

Particularly relevant research for the future will examine integrative systems that combine multiple strategies, for example, experiments that combine techniques such as bioactive soil amendments with solarization. Such new management strategies and combinations must be feasible and relevant to existing systems if they are to be implemented. Confirming the commercial viability of new innovations, such as the use of no-till techniques in commercial processing tomatoes, will also contribute to their success. Valuable UC research is in progress focusing on breeding for direct resistance to soilborne pests using advances such as molecular marker-assisted identification of resistance genes. Less well studied though, is the idea of breeding for indirect resistance by recruiting beneficial microbes or repelling pests via root exudates.

Lastly, in working to manage soil health for pest suppression, more work is needed on diagnostics to determine what constitutes a "healthy" soil. As a step towards future testing for beneficial organisms, databases of microbial communities could be expanded, relating them to management practices and disease presence. Soil health tests developed outside California will require validation in local cropping systems, and the relationship between soil health scores and desired outcomes such as increased yields and nutrient retention will need to be confirmed. With future advances in UC research, managing for soil health could become an integral component of pest management, resulting in more resilient and productive cropping systems that provide multiple agronomic and environmental benefits. CA

\section{A. Hodson is Project Scientist in the Department of Entomology and Nematology at UC Davis and E. Lewis is Associate Dean for Agricultural Sciences in the College of Agricultural and Environmental Sciences and Professor in the Department of Entomology and Nematology at UC Davis. \\ We thank the California Department of Pesticide Regulation (DPR) for support of this research; the panelists and attendees of 2014 Soil Health Symposium for their input; and the anonymous reviewers whose comments improved the manuscript considerably. DPR provided partial or full funding for this project but does not necessarily agree with any opinion expressed, nor endorse any commercial product or trade name mentioned.}

\section{References}

Badri DV, Quintana N, El Kassis EG, et al. 2009. An ABC transporter mutation alters root exudation of phytochemicals that provoke an overhaul of natural soil microbiota. Plant Physiol 151:2006-17.

Baker JB, Southard RJ, Mitchell JP. 2005. Agricultural dust production in standard and conservation tillage systems in the San Joaquin Valley. J Environ Qual 34:1260-9.
Baker KF. 1948. Nursery seedlings: improved methods of production possible with control of damping-off disease. Calif Agr 2:10-4.

Baker KF, Smith SH. 1967. Modern methods of disease control in florist and nursery crops. Calif Agr 21:10-2.Bakker MG, Manter DK, Sheflin AM, et al. 2012. Harnessing the rhizosphere microbiome through plant breeding and agricultural management. Plant Soil 360:1-13.
Baumgartner K, Fujiyoshi P, Browne GT. 2013. Evaluating paradox walnut rootstocks for resistance to armillaria root disease. Hortscience 48:68-72.

Berendsen RL, Pieterse CMJ, Bakker PAHM. 2012. The rhizosphere microbiome and plant health. Trends Plant Sci 17:478-86. 
Browne GT, Lampinen BD, Holtz BA, et al. 2013. Managing the almond and stone fruit replant disease complex with less soil fumigant. Calif Agr 67:128-38.

Brussaard L, de Ruiter PC. 2007. Soil biodiversity for agricultural sustainability. Agric Ecosyst Environ 121:233-44.

Cavigelli MA, Maul JE, Szlávecz K. 2012. Managing soil biodiversity and ecosystem services. In: Wahl DH, et al. (eds.). Soil Ecology and Ecosystem Services. Oxford University Press. p 337-56.

Coleman-Derr D, Tringe SG. 2014. Building the crops of tomorrow: advantages of symbiont-based approaches to improving abiotic stress tolerance. Front Microbiol 5:1-6. Dill-Macky R, Jones RK. 2000. The effect of previous crop residues and tillage on fusarium head blight of wheat Plant Dis 84:71-6.

Doran JW, Sarrantonio M, Liebig M. 1996. Soil health and sustainability. Adv Agron 56:1-54.

Drenovsky RE, Duncan RA, Scow KM. et al. 2005. Soil sterilization and organic carbon, but not microbial inoculants, change microbial communities in replanted peach orchards. Calif Agr 59: 176-81.

Eilenberg J, Hajek A, Lomer C. 2001. Suggestions for unifying the terminology in biological control. BioControl 46:387-400.

Farm Foundation NFP. 2014. Soil Renaissance Strategic Plan. http://soilrenaissance.org/wp-content/uploads/2014/06/SRstrategicplan.pdf.

Fennimore SA, Serohijos R, Samtani JB, et al. 2013. TIF film, substrates and nonfumigant soil disinfestation maintain fruit yields. Calif Agr 67:139-46.

Fennimore SA, Martin FM, Miller TC, et al. 2014. Evaluation of a mobile steam applicator for soil disinfestation in California strawberry. Hortscience 49:1542-49.

Ferris H, Tuomisto H. 2015. Unearthing the role of biolog cal diversity in soil health. Soil Biol Biochem 85:101-09.

Flor-Peregrín E, Azcón R, Martos V. et al. 2014. Effects of dual inoculation of mycorrhiza and endophytic, rhizospheric or parasitic bacteria on the root-knot nematode disease of tomato. Biocontrol Sci Technol 24:1122-36.

Gamliel A, Stapleton JJ. 1993. Effect of chicken or compost ammonium phosphate and solarization on pathogen control, rhizosphere microorganisms, and lettuce growth. Plant Dis 77: 886-91.

Hao J, Subbarao KSV. 2003. Effects of broccoli rotation on lettuce drop caused by Sclerotinia minor and on the population density of Sclerotia in soil. Plant Dis 87:159-166.

Hartz TK, DeVay JE, Elmore CL. 1993. Solarization is an effective soil disinfestation technique for strawberry production. Hortscience 28:104-6.

Hewavitharana SS, Ruddell D, Mazzola M. 2014. Carbon source-dependent antifungal and nematicidal volatiles derived during anaerobic soil disinfestation. Eur J Plant Pathol 140:39-52.

Hoagland L, Carpenter-Boggs L, Reganold JP, Mazzola M. 2008. Role of native soil biology in Brassicaceous seed meal-induced weed suppression. Soil Biol Biochem 40:1689-97.

Ingels C, Van Horn M, Bugg R, Miller PR. 1994. Selecting the right cover crop gives multiple benefits. Calif Agr 48:43-8

Jackson LE, Ramirez IR, Yokota R, et al. 2003. Scientists, growers assess trade-offs in use of tillage, cover crops and compost. Calif Agr 57:48-54.

Jaffee BA. 2004. Do organic amendments enhance the nematode-trapping fungi Dactylellina haptotyla and Arthrobotrys oligospora? J Nematol 36:267-75.

Janvier C, Villeneuve F, Alabouvette C, et al. 2007. Soi health through soil disease suppression: Which strategy from descriptors to indicators? Soil Biol Biochem 39:1-23.

Kaloshian I, Williamson VM, Miyao G, et al. 1996. "Resistance-breaking" nematodes identified in California tomatoes. Calif Agr 50:18-9.
Kloepper JW, Leong J, Teintze M, Schroth MN. 1980a. Enhanced plant growth bysiderophores produced by plant growth-promoting rhizobacteria. Nature 286:885-6.

Kloepper JW, Leong J, Teintze M, Schroth MN. 1980b. Pseudomonas siderophores: A mechanism explaining disease-suppressive soils. Curr Microbiol 4:317-20. Kluepfel D, Browne G, McKenry M, et al. 2014. Development of disease-resistant walnut rootstocks: integration of conventional and genomic approaches. http://ucanr. edu/repositoryfiles/2013_77_ocr.pdf-154601.pdf.

Koike ST, Subbarao KV. 2000. Broccoli residues can control Verticillium wilt of cauliflower. Calif Agr 54:30-3.

Lehman R, Acosta-Martinez V. 2015. Soil biology for resilient, healthy soil. J Soil Water Conserv 70:12-8.

Loper JE, Hassan KA, Mavrodi DV, et al. 2012. Comparative genomics of plant-associated Pseudomonas spp.: Insights into diversity and inheritance of traits involved in multitrophic interactions. PLoS Genet 8:e1002784.

Mankau R. 1959. Natural enemies of nematodes: Studies of complex soil environment aimed at favoring fungi and other organisms that limit plant nematode populations. Calif Agr 13:24.

Mazzola M. 2004. Assessment and management of soil microbial community structure for disease suppression. Annu Rev Phytopathol 42:35-59.

Mazzola M, Hewavitharana SS, Strauss SL. 2015. Brassica seed meal soil amendments transform the rhizosphere microbiome and improve apple production through resistance to pathogen reinfestation. Phytopathology 105:460-9.

Mazzola M, Muramoto J, Shennan C. 2012. Transformation of soil microbial community structure in response to anaerobic soil disinfestation for soilborne disease contro in strawberry. American Phytopathological Society Annual Meeting, Aug. 2-8, 2012. Providence, RI. p 77-8.

McKenry M, Buzo T, Kretsch J, et al. 1994. Soil fumigants provide multiple benefits; alternatives give mixed results Calif Agr 48:22-8.

Mendes R, Garbeva P, Raaijmakers JM. 2013. The rhizosphere microbiome: significance of plant beneficial, plant pathogenic, and human pathogenic microorganisms. FEMS Microbiol Rev 37:634-63.

Mitchell JP, Klonsky KM, Miyao EM, et al. 2012. Evolution of conservation tillage systems for processing tomato in California's Central Valley. Hortechnology 22:617-26.

Mitchell JP, Shrestha A, Horwath WR, et al. 2015. Tillage and cover cropping affect crop yields and soil carbon in the San Joaquin Valley, California. Agron J 107:588-96.

Mitchell JP, Singh PN, Wallender WW, et al. 2012. Notillage and high-residue practices reduce soil water evaporation. Calif Agr 66:55-61.

[NRCS] Natural Resources Conservation Service. 2014 Soil health. www.nrcs.usda.gov/wps/portal/nrcs/main/ national/soils/health/.

Nielsen MN, Winding A. 2002. Microorganisms as indicators of soil health. NERI Technical Report No. 388 Roskilde, Denmark: Ministry of the Environment, National Environmental Research Institute.

Pankhurst CE, Doube BM, Gupta VVSR. 1997. Biological indicators of soil health. CAB International.

Pellkofer S, van der Heijden MG, Schmid B, Wagg C. 2016 Soil communities promote temporal stability and species asynchrony in experimental grassland communities. PLoS One 11: e0148015.

Ramirez-Villapudua J, Munnecke DE. 1986. Solar heating and amendments control cabbage yellows. Calif Agr 40:11-3.

Samtani JB, Gilbert C, Weber JB, et al. 2012. Effect of steam and solarization treatments on pest control, strawberry yield, and economic returns relative to methy bromide fumigation. Hortscience 47: 64-70.

Scott JC, Gordon T, Kirkpatrick S, et al. 2012. Crop rotation and genetic resistance reduce risk of damage from Fusarium wilt in lettuce. Calif Agr 66:20-4.
Shennan C, Muramoto J, Lamers J, et al. 2013. Optimizing anaerobic soil disinfestation for soilborne disease control. Annu Int Res Conf Methyl Bromide Altern Emiss: 1-4.

Shennan C, Muramoto J, Lamers J, et al. 2014. Anaerobic soil disinfestation for soil borne disease control in strawberry and vegetable systems: Current knowledge and future directions. Acta Hortic 1044:165-175.

Shrestha A, Browne GT, Lampinen BD, et al. 2008. Perennial crop nurseries treated with methyl bromide and alternative fumigants: Effects on weed seed viability, weed densities, and time required for hand weeding. Weed Technol 22:267-74.

Simmons CW, Guo H, Claypool JT, et al. 2013. Managing compost stability and amendment to soil to enhance soi heating during soil solarization. Waste Manag 33:1090-6.

Simmons CW, Claypool JT, Marshall MN, et al. 2014. Characterization of bacterial communities in solarized soil amended with lignocellulosic organic matter. Appl Soil Ecol 73:97-104.

Singer S, Ewing M. 2000. Soil quality. In: Sumner ME (ed.). Handbook of Soil Science. CRC Press. p G271-8.

Smith KP, Handelsman JGR. 1999. Genetic basis in plants for interactions with disease-suppressive bacteria. Proc Natl Acad Sci U S A 96: 4786-90.

Stapleton JJ. 2000. Soil solarization in various agricultural production systems. Crop Prot 19:837-41.

Stapleton JJ, Bañuelos GS. 2009. Biomass crops can be used for biological disinfestation and remediation of soils and water. Calif Agr 63:41-6.

Stapleton JJ, Duncan RA. 1998. Soil disinfestation with cruciferous amendments and sublethal heating: effects on Meloidogyne incognita, Sclerotium rolfsii and Pythium ultimum. Plant Pathol 47:737-42.

Stapleton JJ, Elmore CL, DeVay JE. 2000. Solarization and biofumigation help disinfest soil. Calif Agr 54:42-5.

Stapleton JJ, Molinar RH, Lynn-Patterson K, et al. 2005. Soil solarization provides weed control for limitedresource and organic growers in warmer climates. Calif Agr 59:84-9.

Summers CG, Mitchell JP, Prather TS, Stapleton JJ. 2009. Sudex cover crops can kill and stunt subsequent tomato, lettuce and broccoli transplants through allelopathy. Calif Agr 63:35-40.

Suslow TV, Kloepper JW, Schroth MN, Burr TJ. 1979. Beneficial bacteria enhance plant growth. Calif Agr 33:15-7.

van Bruggen AHC, Semenov AM. 2000. In search of bioogical indicators for soil health and disease suppression. Appl Soil Ecol 15:13-24.

van der Heijden MGA, Bardgett RD, van Straalen NM. 2008. The unseen majority: soil microbes as drivers of plant diversity and productivity in terrestrial ecosystems. Ecol Lett 11:296-310.

Veenstra J, Horwath WR, Mitchell JP. 2007. Tillage and cover cropping effects on aggregate-protected carbon in cotton and tomato. Soil Sci Soc Am J 71:362-71.

Visser S, Parkinson D. 1992. Soil biological criteria as indicators of soil quality: Soil microorganisms. Am J Altern Agric 7:33-7.

Wagg C, Bender SF, Widmer F, van der Heijden MGA 2014. Soil biodiversity and soil community composition determine ecosystem multifunctionality. Proc Natl Acad Sci U S A 111:5266-70.

Wardle DA. 1995. Impacts of disturbance on detritus food webs in agro-ecosystems of contrasting tillage and weed management practices. Adv Ecol Res 26:105-85.

Yaghoobi J, Yates JL, Williamson VM. 2005. Fine mapping of the nematode resistance gene Mi-3 in Solanum peruvianum and construction of a S. Iycopersicum DNA contig spanning the locus. Mol Genet Genomics 274:60-9. 